\title{
The Janus serum bank and biomarkers of cancer
}

\author{
Randi Gislefoss ${ }^{1,2}$ and Egil Jellum ${ }^{1}$ \\ 1) Institute of Clinical Biochemistry, Rikshospitalet, Oslo \\ 2) The Norwegian Cancer Registry, Oslo \\ Correspondence: Randi Gislefoss, The Norwegian Cancer Registry, Montebello, NO-0310 Oslo, Norway \\ E-mail: reg@kreftregisteret.no
}

\begin{abstract}
The Janus serum bank, established in 1973, contains sera stored at -25 degrees collected from 330,000 originally healthy individuals. The number of cancer cases have increased from zero in 1973 to more than 50,000 in 2005, including invasive and non-invasive cancers. Information on cases have been obtained by coupling the Janus file against the Norwegian Cancer Registry. The sera have been used in over 70 different cancers research projects, usually in case-control studies and in collaboration with national and international research groups. The type of biomarker analysed include antibodies against Chlamydia, CMV, Epstein Barr virus, HPV and Helicobacter pylori. Leptin, long chain fatty acids, androgens and other hormones, vitamins as well as environmental toxins such as organochlorines are other types of cancer biomarkers investigated. Mutation analyses (BRCA-1 etc) have been possible using PCR and the trace amounts of DNA remaining in the sera.
\end{abstract}

\section{NORSK SAMMENDRAG}

Janus serum bank ble etablert i 1973 og inneholder sera lagret ved -25 grader, innsamlet fra 330.000 opprinnelig friske personer. Antall krefttilfeller har steget fra null i 1973 til over 50.000 i år 2005, inkludert både invasiv og ikke-invasiv kreft. Informasjon om kasus er tilgjengelig ved å koble Janus-filene mot Kreftregisterets databaser. Serumprøvene er blitt benyttet i over 70 forskjellige kreftforskningsprosjekter, som oftest i kasus-kontroll studier og i samarbeide med en rekke nasjonale og internasjonale forskningsgrupper. Mange ulike biomarkører på kreft er blitt analysert, bl.a. antistoffer mot Chlamydia, CMV, Epstein Barr virus, HPV og Helicobacter pylori. Leptin, lange fettsyrer, androgener og andre hormoner, vitaminer såvel som miljøgifter av typen organiske klorforbindelser er eksempler på andre kreftbiomarkører som er undersøkt. Det har også vært mulig å gjøre mutasjonsanalyser (BRCA-1 etc) ved å bruke PCR til å amplifisere opp den spormengden DNA som finnes i serum.

\section{BACKGROUND}

The "Janus-idea" was proposed by O. Torgersen (1907-1978), a professor of pathology at Rikshospitalet, Oslo, in the late sixties. He suggested to commence collection of a few $\mathrm{mL}$ of serum from a large number of presumably healthy persons, and store the samples in a deep-freezer. As time passes he argued, some of the blood donors will inevitably develop some type of cancer. By coupling the information from the Norwegian Cancer Registry with the Janus-protocols, one could easily identify the cancer cases. These samples could then be used to search for changes in chemical, biochemical, immunological or other compounds that might indicate cancer development at early stages, or be indicative of increased risk of cancer.

Although the idea was rejected by many at first, funding was made available from the Norwegian Cancer Society in 1973, which was the year when the Janus serum bank was established.

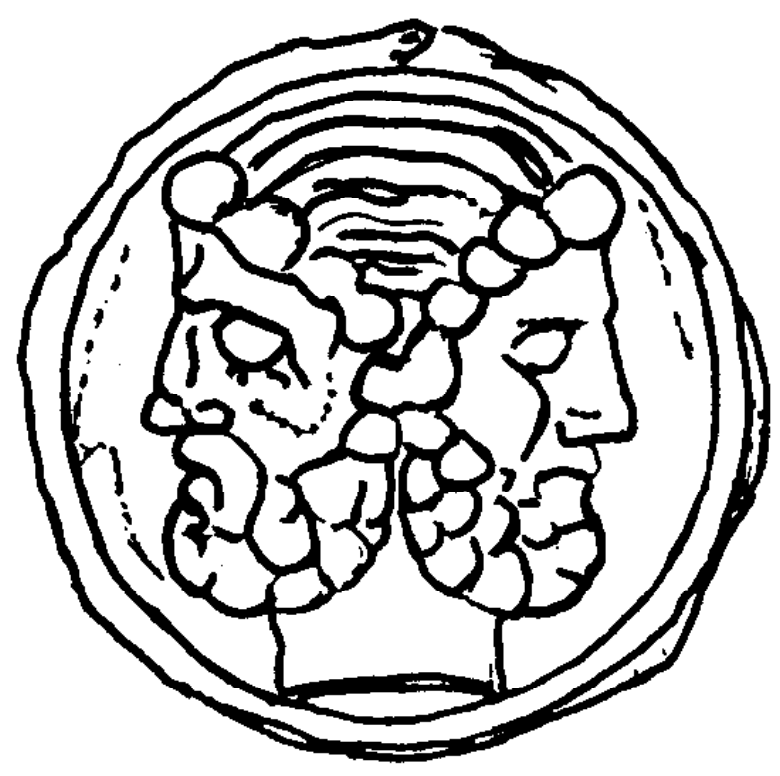




\section{THE JANUS SERUM BANK}

The Janus serum bank is currently one of the oldest and largest biobanks available, containing sera from more than 330,000 individuals who have donated from 1 to 13 samples (average 2.2) each. About 30 per cent of the sera stem from Red Cross Blood Donors in Oslo, whereas the majority of the samples originate from persons undergoing regular health examinations in many counties in Norway. The number of cancer cases have increased from zero in 1973 to more than 50,000 in 2005 , including invasive and non-invasive cancers.

One of the critisisms of the bank is the storage temperature, which is -25 degrees C. A number of stability experiments have, however, confirmed that many compounds are surprisingly stable at this temperature. Even if a compound is slowly degraded over the years, the use of age-, sex-, and storage-matched controls may compensate for this slow decomposition.

The Janus bank has been owned by the Norwegian Cancer Society up to May 1, 2005, after which date the responsibility was transferred to the Norwegian Cancer Registry.

A steering board has administered the use of the biobank in all these years, and has reviewed all the project proposals received from reseachers in Norway and abroad.

\section{USE OF THE JANUS BANK IN CANCER RESEARCH}

During the first 10-15 years of the Janus-bank, collection of sera was given the highest priority. Furthermore, during this period the number of cancers were too few to be able to carry out case-control studies with sufficient statistical power to draw safe conclusions.
The very first study was carried out in 1982 where an anti-tumor response in the preclinical period of lung cancer was reported. Some years later (1988/89) more typical cancer markers like CA-125 and Epstein Barr virus were examined in relation to ovarian cancer and Hodgkins disease, respectively. It was not until the late 1990 's, however, that the scientific use of the biobank was clearly manifested. Collaboration with many groups, particularly in Scandinavia, but also in Europe and USA, were initiated, and a number of results were achieved and presented.

In general, a given biomarker is analysed in a number of cases (e.g. 500 breast cancers) and in 3 times as many matched controls (sera from Janus donors without cancer)

The cases and controls are retrieved from the large commercial storage freezer according to lists provided by the Cancer Registry. After thawing and aliquoting the samples are coded and shipped on dry-ice to the collaborating laboratory. After completion of the analyses, the code is broken and statistical analysis carried out. In this way bias is avoided and the anonymity of the Janus donor is always preserved.

\section{BIOMARKERS OF CANCER STUDIED IN THE JANUS SERA}

Up to now about 50 different projects have been completed and published and about fifteen more studies are currently under way. It is, however, outside the scope of this paper to discuss the indivual papers and results obtained. Clearly, in all these studies a number of different biomarkers have been examined in relation to different types of cancer. This is summarized in the table shown below. For further details the reader may consult the rerences given and the website: www.kreftsaken.no with links to Janus.

\section{JANUS PROJECTS, PUBLICATION LIST UPDATED NOVEMBER 2005}

1. Kotlar HK, Sanner T, Eker P, Pihl A, Ørjasæter H, Harvei S, Theodorsen L, Jellum E. Anti-tumor response in the preclinical period of lung cancer. Eur J Cancer Clin Oncol 1982; 18: 317-319.

2. Jellum E, Andersen Aa, Ørjasæter H, Foss OP, Theodorsen L, Lund-Larsen P. The JANUS serum bank and early detection of cancer. Biochim Clinica 1987; 11: 191-195.

3. Thoresen SØ, Myking O, Glattre E, Rootwelt K, Andersen A, Foss OP. Serum thyroglobuline as a preclinical tumor marker in subgroups of thyroid cancer. Brit J Cancer 1988; 57: 105-108.

4. Zurawski VR, Ørjasæter H, Andersen A, Jellum E. Elevated serum CA 125 levels prior to diagnosis of ovarian neoplasia: relevance for early detection of ovarian cancer. Int J Cancer 1988; 42: 677-680.

5. Mueller N, Evans A, Harris N, Comstock GW, Jellum E, Magnus K, Orentreich N, PolkVogelman J. Hodgkin's disease and Epstein-Barr virus: Altered antibody pattern before diagnosis. N Engl J Med 1989; 320: $689-695$.

6. Glattre E, Thomassen Y, Thoresen SØ, Lund-Larsen PG, Theodorsen L, Aaseth J. Prediagnostic serum selenium in a case-control study of thyroid cancer. Int J Epidemiol 1989; 18: 45-49.

7. Jellum E, Thorsrud AK. Profiling cells and body fluids - chromatography and 2-D electrophoresis as complementary techniques. J Chromatogr 1989; 488: 105-127. 
8. Mueller N, Mohar A, Evans A, Harris N, Comstock G, Jellum E, Magnus K, Orentreich N, Polk BF, Vogelman J. Epstein-Barr virus antibody patterns preceding the diagnosis of non-Hodgkin's lymphoma. Int $J$ Cancer 1991; 49: 387-393.

9. Chan CK, Mueller N, Evans A, Harris NL, Comstock GW, Jellum E, Magnus K, Orentreich N, Polk BF, Vogelman J. Epstein-Barr virus antibody patterns preceding the diagnosis of nasopharyngeal carcinoma. Cancer Causes Control 1991: 2: 125-131.

10. Jellum E, Andersen Aa, Lund-Larsen P, Theodorsen L, Ørjasæter H. The JANUS serum bank. Sci Total Environ 1993; 139/140: 527-535.

11. Vatten L, Bjerve K, Andersen Aa, Jellum E. Polyunsaturated fatty acids in serum phospholipids and risk of breast cancer: a case control study from the Janus serum bank in Norway. Eur J Cancer 1993; 29A: 532-538.

12. Paus E, Theodorsen L, Engeland A. Prostate specific antigen in serum from blood donors with subsequent cancer prostate diagnosis. Eur J Cancer 1993; 29A: 1221-1222.

13. Parsonnet J, Hansen S, Rodriguez L, Gelb AB, Warnke RA, Jellum E, Orentreich N, Vogelman J, Friedman GD. Helicobacter pylori infection and gastric lymphoma. N Engl J Med 1994; 330: 1267-1271. Editorial (P.G. Isaacson) Gastric lymphoma and Helicobacter pylori, N Engl J Med 1994; 330: 1310-1311.

14. Berg JP, Glattre E, Haldorsen T, Høstmark A, Bay I, Johansen A, Jellum E. Long chain serum fatty acids and risk of thyroid cancer: a population-based case-control study in Norway. Cancer Causes Control 1994; 5: 433-439.

15. Jellum E, Andersen Aa, Lund-Larsen P, Theodorsen L, Ørjasæter H. Experiences of the Janus Serum Bank in Norway. Environ Health Perspect 1995; 103: 85-88.

16. Jellum E, Andersen Aa, Baklien K, Dalen A, Iversen OE, Lund-Larsen P, Theodorsen L, Ørjasæter H. Use of the Janus serum bank in studies related to the environment and cancer. Norwegian Acad Sci Letters 1996: 23 32.

17. Jellum E, Dollekam H, Blessum C. Capillary electrophoresis for clinical problem solving: Analysis of urinary diagnostic metabolites and serum proteins. J Chromatogr B Biomed Appl 1996; 683: 55-65 (Stability of Janus sera discussed).

18. Dillner J, Lehtinen M, Bjørge T, Luostarinen T, Youngman L, Jellum E, Koskela P, Gislefoss R, Hallmans G, Paavonen J, Sapp M, Schiller J, Hakulinen T, Thoresen S, Hakama M. Prospective seroepidemiologic study of human papilloma virus infection as a risk factor for invasive cervical cancer. J Natl Cancer Inst 1997; 89: 1293-1299.

19. Bjørge T, Dillner J, Antilla T, Engeland A, Hakulinen T, Jellum E, Lehtinen M, Luostarinen T, Paavonen J, Pukkala E, Sapp M, Schiller J, Youngman L, Thoresen S. Prospective seroepidemiologic study of human papillomavirus in non-cervical anogenital cancers. Brit Med J 1997; 315: 646-649.

20. Jellum E, Dollekamp H, Brunsvig A, Gislefoss R. Diagnostic applications of chromatography and capillary electrophoresis. J Chromatogr B 1997; 689: 155-164 (Myelomatosis results included).

21. Harvei S, Bjerve KS, Tretli S, Jellum E, Robsahm TE, Vatten L. Prediagnostic level of fatty acids in serum phospholipids: omega-3 and omega-6 fatty acids and the risk of prostate cancer. Int J Cancer 1997; 71: 545551.

22. Witherell HL, Hansen S, Jellum E, Orentreich N, Vogelmann JH, Parsonnet J. Risk for gastric lymphoma in persons with $\mathrm{CagA}^{+}$and $\mathrm{CagA}^{-}$Helicobacter pylori infection. J Infect Dis 1997; 176: 1641-1644.

23. Bjørge T, Hakulinen T, Engeland A, Jellum E, Koskela P, Lehtinen M, Luostarinen T, Paavonen J, Sapp M, Schiller J, Thoresen S, Wang Z, Youngman L, Dillner J. A prospective, seroepidemiological study of the role of human papillomavirus in esophageal cancer in Norway. Cancer Res 1997; 57: 3989-3992.

24. Jellum E, Andersen Aa, Baklien K, Dalen A, Iversen OE, Lund-Larsen P, Theodorsen L, Ørjasæter H, Brunsvig A, Gislefoss R. Use of the Janus serum bank in cancer research. NORD Biotechn 1997; 9: 43-52.

25. Vatten L, Ursin G, Ross RK, Stanczyk FZ, Lobo RA, Harvei S, Jellum E. Androgens in serum and the risk of prostate cancer: A nested case-control study from the Janus serum bank in Norway. Cancer Epidemiol Biomarkers Prev 1997; 6: 967-969.

26. Luostarinen T, af Geijersstam V, Bjørge T, Eklund C, Hakama M, Hakulinen T, Jellum E, Koskela P, Paavonen J, Pukkala EI, Schiller JT, Thoresen S, Youngman LD, Dillner J, Lehtinen M. No excess risk of cervical carcinoma in women seropositive for both HPV16 and HPV6/11. Int J Cancer 1999; 80: 818-822.

27. Koskela P, Anttlila T, Bjørge T, Brunsvig A, Dillner J, Hakama M, Hakulinen T, Jellum ER, Lehtinen M, Lenner P, Luostarinen T, Pukkala E, Saikko P, Thoresen S, Youngman L, Paavonen J. Chlamydia trachomatis infection as a risk factor for invasive cervical cancer. Int J Cancer 2000; 85: 35-39.

28. Berg JP, Egeland A, Jellum E, Glattre E. Serum dehydroepiandrosterone sulfate concentration and thyroid cancer risk: A matched case-control study. Thyroid 1999; 9: 285-288.

29. Akre O, Lipworth L, Tretli S, Linde A, Engstrand L, Adami H-O, Melbye M, Andersen Aa, Ekbom A. Epstein-Barr virus and cytomegalovirus in relation to testicular cancer risk: A nested case-control study. Int $J$ Cancer 1999; 82: 1-5. 
30. Hansen S, Melby KK, Aase S, Jellum E, Vollset SE. Helicobacter pylori infection and risk of cardia cancer and non-cardia gastric cancer. A nested case-control study. Scand J Gastroenterol 1999; 34: 353-360.

31. Hakama M, Luostarinen T, Dillner J, Hallmans G, Jellum E, Koskela P, Lehtinen M, Thoresen S, Youngman L, Hakulinen T. Joint effect of HPV16 with Clamydia trachomatis and smoking on risk of cervical cancer: antagonism or misclassification (Nordic countries). Cancer Causes Control 2000; 11: 783-790.

32. Ward EM, Schulte P, Grajewski B, Andersen A, Patterson DG Jr, Turner W, Jellum E, Deddens JA, Friedland J, Roeleveld N, Waters M, Butler MA, DiPietro E, Needham LL. Serum organochlorine levels and breast cancer: A nested case-control study of Norwegian Women. Cancer Epidemiol Biomarkers Prev 2000; 9: 1357-1367.

33. Anttila T, Saikku P, Koskela P, Bloigu A, Dillner J, Ikaheimo I, Jellum E, Lehtinen M, Lenner P, Hakulinen T, Narvanen A, Pukkala E, Thoresen S, Youngman L, Paavonen J. Serotypes of Chlamydia trachomatis and the risk for cervical squamous cell carcinoma. JAMA 2001; 285: 47-51.

34. Bjørge T, Engeland A, Luostarinen T, Mork J, Gislefoss RE, Jellum E, Koskela P, Lethinen M, Pukkala R, Thoresen S, Dillner J. Human papillomavirus infection as a risk factor for anal and perianal skin cancer in a prospective study. Brit J Cancer 2002; 87: 61-64.

35. Mork J, Lie K, Glattre E, Clark S, Hallmans G, Jellum E, Koskala P, Møller B, Pukkala E, Schiller JT, Wang Z, Youngman L, Lethinen M, Dillner J. Human papillomavirus infection as a risk factor for squamous-cell carcinoma of the head and neck carcinomas. N Engl J Med 2001; 344: 1125-31.

36. Høstmark AT, Glattre E, Jellum E. Effect of long-term storage upon the concentration of albumin and free fatty acids in human serum. Scand J Clin Lab 2001; 61: 443-447.

37. Lethinen M, Pawlita M, Zumbach K, Abeler V, Hakama M, Jellum E, Koskela P, Luostarinen T, Pavonen J, Pukkala E, Sigstad E, Thoresen S, Dillner J. Evaluation of antibody response to human papillomavirus early proteins in women in whom cervical cancer developed 1 to 20 years later. Am J Obstet Gyn 2003; 188: 49-55.

38. Lethinen M, Koskela P, Jellum E, Bloigu A, Anttila T, Hallmans G, Luukkaala T, Thoresen S, Youngman L, Dillner J, Hakama M. Herpes simplex virus and risk of cervical cancer; A longitudinal nested case-control study in the nordic countries. Am J Epidemiol 2002; 15: 687-692.

39. Tuohimaa P, Tekanen L, Ahonen M, Lumme S, Jellum E, Hallmans G, Stättin P, Harvei S, Hakulinen T, Luostarinen T, Dillner J, Lethinen M, Hakama M. Both high and low level of blood vitamin D are associated with a higher prostate cancer risk: A longitudinal, nested case-control study in the Nordic countries. Int $J$ Cancer 2002; 108 (1): 104-108.

40. Luostarinen T, Lehtinen M, Bjørge T, Abler V, Hakama M, Hallmans G, Jellum E, Koskela P, Lenner P, Lie AK, Paavonen J, Pukkala E, Saikku P, Sigstad E, Thoresen S, Youngman LD, Dillner J, Hakulinen T. Joint effects of different human papillomaviruses and Chlamydia trachomatis infections on risk of squamous cell carcinoma of the cervix uteri. Eur J Cancer 2004; 40: 1058-1065.

41. Sigstad E, Lie AK, Luostarinen T, Dillner J, Jellum E, Lethinen M, Thoresen S, Abeler V. A prospective study of the relationship between prediagnostic human papillomavirus seropositivity and HPV DNA in subsequent cervical carsinomas. Brit J Cancer 2002; 87: 175-180.

42. Stattin P, Adlercreutz H, Tekanen L, Jellum E, Lumme S, Hallmans G, Harvei S, Teppo L, Stumpf K, Luostarinen T, Lethinen M, Dillner J, Hakama M. Circulating enterolactone and prostate cancer risk: a Nordic nested case-control study. Int J Cancer 2002; 99: 124-129.

43. Paavonen J, Karunakaran KP, Noguchi Y, Anttila T, Bloigu A, Dillner J, Hallmans G, Hakulinen T, Jellum E, Koskela P, Lehtinen M, Thoresen S, Lam H, Shen C, Brunham RC. Serum antibody response to the HSP60s of Chlamydia trachomatis in women with cervical cancer. Am J Obstet Gynecol 2003; 189 (5): 1287-1292.

44. Tuohimaa P, Tenkanen L, Ahonen M, Lumme S, Jellum E, Hallmans G, Stattin P, Harvei S, Hakulinen T, Luostarinen T, Dillner J, Lehtinen M, Hakama M. Both high and low level of blood vitamin D are associated with a higher prostate cancer risk: A longitudinal, nested case-control study in the nordic countries. Int $J$ Cancer 2004; 108: 104-108.

45. Stattin P, Kaaks R, Johansson R, Gislefoss R, Söderberg S, Alfthan H, Stenman U-H, Jellum E, Olsson T. Plasma leptin is not associated with prostate cancer risk. Cancer Epidemiol Biomarkers Prev 2003; 12 (5): 474-475.

46. Stattin P, Lumme S, Tenkanen L, Alfthan H, Jellum E, Hallmans G, Thoresen S, Hakulinen T, Luostarinen T, Lehtinen M, Dillner J, Stenman U-H, Hakama M. High levels of circulating testosterone are not associated with increased prostate cancer risk: A pooled prospective study. Int J Cancer 2004; 108 (3): 425-432.

47. Stattin P, Biessy C, Lukanova A, Söderberg S, Palmquist R, Kaaks R, Olsson T, Jellum E. Obesity and colon cancer: does leptin provide a link? Int J Cancer 2004; 150 (2): 161-171.

48. Anttila T, Tenkanen L, Lumme S, Leinonen M, Gislefoss RE, Hallmans G, Thoresen S, Hakulinen T, Luostarinen T, Stattin P, Saikku P, Dillner J, Lehtinen M, Hakama M. Chlamydial antibodies and risk of prostate cancer. Cancer Epidemiol Biomarkers Prev 2005; 14: 385-389.

49. Ulvik A, Vollset SE, Hansen S, Gislefoss RE, Jellum E, Ueland PM. Colorectal cancer and the methylene tetrahydrofolate reductase $677 \mathrm{C} \rightarrow \mathrm{T}$ and methionine synthase $2756 \mathrm{~A} \rightarrow \mathrm{G}$ polymorphisms. A prospective study of 2168 case-control pairs from the JANUS cohort. Cancer Epidemiol Biomarkers Prev 2004; 13: 2175-2180. 
50. Jellum E, Gislefoss E. Serumbank "Janus" i kreftforskning. Fra håndverk til høyteknologi. Klinisk kjemi på Rikshospitalet fra 1953 til 2003. 2003: 403-415.

51. Bjørge T, Lie AK, Hovig E, Gislefoss RE, Hansen S, Jellum E, Langseth H, Nustad K, Tropé CG, Dørum A. BRCA1 mutations in ovarian cancer and borderline tumors in Norway. Brit J Cancer 2004; 91: 1829-1834.

52. Ekstrøm PO, Bjørge T, Dørum A, Longva AS, Heintz K-M, Warren DJ, Hansen S, Gislefoss RE, Hovig E. Determination of hereditary mutations in the BRCA 1 gene using archived serum samples and capillary electrophoresis. Anal Chem 2004; 76: 4406-4409.

53. Tedeschi R, Luostarinen T, De Paoli P, Gislefoss RE, Tenkanen L, Virtamo J, Koskela P, Hallmans G, Lehtinen M, Dillner J. Joint Nordic prospective study on human herpesvirus 8 and multiple myeloma risk. $\mathrm{Br}$ $J$ Cancer 2005; 93: 834-837.

54. Korodi Z, Dillner J, Jellum E, Lumme S, Hallmans G, Thoresen S, Hakulinen T, Stattin P, Luostarinen T, Lehtinen M, Hakama M. Human papillomavirus 16, 18, and 33, infections and risk of prostate cancer: a Nordic nested case-control study. Cancer Epidemiol Biomarkers Prev 2005; 14: 2952-2955.

Table 1. Cancer projects derived from the Janus bank.

\begin{tabular}{|c|c|c|}
\hline Biomarkers & Type of Cancer & Reference no. \\
\hline Breast cancer antigen-1 mutation & Breast & 51,52 \\
\hline Cancer Antigen-125 & Ovarian & 4 \\
\hline Chlamydia trachomatis antibody & Cervical & $27,31,33,40,43$ \\
\hline Chlamydia trachomatis antibody & Prostate & 48 \\
\hline Cytomegalovirus antibody & Testis & 29 \\
\hline Enterolactone & Prostate & 42 \\
\hline Epstein Barr virus antibody & Hodgkin's disease & 5 \\
\hline Epstein Barr virus antibody & Nasopharyngeal carcinoma & 9 \\
\hline Epstein Barr virus antibody & Non Hodgkin's lymphoma & 8 \\
\hline Epstein Barr virus antibody & Testis & 29 \\
\hline Fatty acids in serum phospholipids & Prostate & 21 \\
\hline Helicobacter pylori antibody & Cardia & 30 \\
\hline Helicobacter pylori antibody & Gastric lymphoma & 13,22 \\
\hline Helicobacter pylori antibody & Non cardia gastric & 30 \\
\hline Herpes simplex antibody & Cervical & 38 \\
\hline Herpesvirus 8 antibody & Multiple myeloma & 53 \\
\hline Human Papilloma virus antibody & Anal and perianal & 34 \\
\hline Human Papilloma virus antibody & Cervical & $18,26,31,37,40,41$ \\
\hline Human Papilloma virus antibody & Esophageal & 23 \\
\hline Human Papilloma virus antibody & Head and neck & 35 \\
\hline Human Papilloma virus antibody & Non cervical anogenital & 19 \\
\hline Leptin & Colon & 47 \\
\hline Leptin & Prostate & 45 \\
\hline Long chain serum fatty acids & Thyroid & 14 \\
\hline Lung cancer antibody & Lung & 1 \\
\hline Methylene tetrahydrofolate reductase gene mutation & Colorectal & 49 \\
\hline Polyunsaturated phospholipids & Breast & 11 \\
\hline Prostate antigen & Prostate & 12 \\
\hline Selenium & Thyroid & 6 \\
\hline Serum androgens & Prostate & 25 \\
\hline Serum dehydroepiandrosterone sulfate & Thyroid & 28 \\
\hline Serum organoclorines & Breast & 32 \\
\hline Serum proteins & Multiple myeloma & 20 \\
\hline Testosterone & Prostate & 46,46 \\
\hline Thyroglobuline & Thyroid & 3 \\
\hline Vitamin D & Prostate & 39,44 \\
\hline
\end{tabular}

